\title{
Buğday Verimi ve Biyokütlesi ile Uzaktan Algılama Vejetasyon İndisleri Arasındaki ílișkilerin Tarımsal İklim Bölgeleri Bazında Değerlendirilmesi
}

\author{
Murat GÜVEN TUĞAÇ ${ }^{1, *}$ (ID) Harun TORUNLAR' (ID) Erol KARAKURT' (ID) Sinan AYDOĞAN' (ID)
}

'Tarla Bitkileri Merkez Araștırma Enstitüsü, Ankara

\begin{abstract}
*Sorumlu yazar (Corresponding author) e-mail: muratguven.tugac@tarimorman.gov.tr
Geliș tarihi (Received): 22.05.2019

Kabul tarihi (Accepted): 19.07.2019

DOI: $10.21657 /$ topraksu.655617
\end{abstract}

\section{Öz}

Tarımsal ürünlerin izlenmesi ve verim öngörülerinin yapılmasında uydu görüntülerinden elde edilen vejetasyon indisleri yaygın olarak kullanılmaktadır. Meteorolojik faktörlerdeki değișimler ve özellikle düzensiz yağıș rejimi farklı ekolojik bölgelerde olumlu ve olumsuz etkiler göstermektedir. Bu çalıșmanın amacı, Tarımsal İklim Bölgeleri (TiB) bazında, spektral vejetasyon indisleri ile verim ve biyokütle arasındaki ilișkilerin araștırılması ve zamansal bazda etkili vejetasyon indislerinin belirlenmesidir. Bu kapsamda, TỉB'in olușturulmasında; Kuraklık indisi ve Etkili Sıcaklık Toplamı (EST) parametreleri kullanılarak 5 farklı bölge belirlenmiștir. Arazi çalıșmalarında, Ankara ve Konya illerinde buğday ekili 108 parsellerden bitki örneklemesi yapılarak verim ve biyokütle değerleri elde edilmiștir.

Bitki gelișme dönemi boyunca, MODIS uydu görüntüsünden elde edilen 15 farklı döneme ait Normalize Edilmiș Bitki İndeksi (NDVI) ile Zenginleștirilmiș Bitki İndeksi (EVI) kullanılmıștır. Vejetasyon indisleri ile biyokütle ve verim arasındaki ilișki Pearson korelasyon katsayısı ile incelenmiștir. Vejetasyon indisleri ile biyokütle arasında en yüksek ilișki; NDVI için Mayıs ayında, 12. dönem (\%75) ve 13. dönem (\%72), EVI için 12. dönem (\%71) ve 13. dönemde (\%72) gerçekleșmiștir. Vejetasyon indisleri ile verim arasında en yüksek korelasyon 12. dönemde, NDVI (\%72) ve EVI (\% 70) olarak tespit edilmiștir. Bitki gelișim dönemi içinde 12. ve 13. dönemler bașaklanma/çiçeklenme dönemine karșlık gelmektedir.

Parametrelerin önemlilik düzeylerine $(p<0.05)$ göre doğrusal regresyon modelleri olușturulmuștur. TiB bazında belirlenen vejetasyon indisleri için olușturulan modeller de R2 değerleri, biyokütleNDVI arasında 0.16 ile 0.84 arasında değișirken alanın bütünü için 0.56 oranında ve biyokütleEVI arasında 0.24 ile 0.68 arasında değișirken alanın bütünü için 0.52 düzeyindedir. Bu oranlar verim ve NDVI arasında 0.28 ile 0.72 arasında değișirken alanın bütününde 0.53 ve verim-EVI arasında 0.32 ile 0.54 arasında değișirken alanın bütünü için 0.48 düzeyindedir. TỉB bazında yapılan tahmin modellerinde alanın bütünü için yapılan modele göre daha yüksek düzeyde ilișkiler elde edilmiștir.

Anahtar kelimeler : Biyokütle, EVI, NDVI, tarımsal iklim bölgeleri, verim 


\title{
Evaluation of the Relationships Between Wheat Yield and Biomass with Remote Sensing Vegetation Indices on the basis of Agricultural Climate Regions
}

\begin{abstract}
Vegetation indices obtained from satellite images are widely used in the monitoring of agricultural crops and the prediction of yields. The changes in meteorological factors and especially the irregular rainfall regime have positive and negative effects on different ecological regions. The aim of this study is to investigate the relationships between spectral vegetation indices, yield and biomass on the basis of agricultural climatic regions (ACZ) and to determine effective vegetation indices on a temporal basis. In this context, 5 different regions were determined by using aridity index and growing degree days (GDD) parameters in establishing ACZ. In the field studies, the plant samples were collected from 108 plots of wheat cultivated in Ankara and Konya provinces and yield and biomass values were obtained.

During the crop growing period, Normalized Vegetation Index (NDVI) and Enhanced Vegetation Index (EVI) of 15 different periods from MODIS satellite image were used. The relationship between vegetation indices and biomass and yield was examined by Pearson correlation coefficient. The highest correlation between vegetation indices and biomass was observed in May in 12th period $(75 \%)$ and 13th period (72\%) for NDVI, 12th period (71\%) and 13th period (72\%) for EVI. The highest correlation rate between vegetation indices and yield was determined as NDVI (72\%) and EVI (70\%) in the 12th period. During the vegetation period, the 12th and 13th periods correspond to the heading / anthesis period.

Linear regression models were created according to the significance levels $(p<0.05)$ of the parameters. The R2 values for the vegetation indexes determined for ACZ-based models ranged from 0.37 to 0.87 for biomass-NDVI and 0.56 for the whole area, 0.24 to 0.68 for the biomass-EVI and 0.52 for the whole area. These ratios vary between 0.28 and 0.72 between yield and NDVI, whereas 0.53 in whole area. The yield-EVI ranges from 0.32 to 0.54 , while it is 0.48 for the whole area. In ACZ based estimation models, a higher level of relationship was obtained than the model made for the whole area.
\end{abstract}

Keywords: Agricultural climate regions, biomass, EVI, NDVI, yield

\section{Gíriș}

Gıda gereksinimi, nüfusun artıșı ve ortalama gelirin yükselmesine bağı olarak giderek artmaktadır (UN-DESA, 2013). Gıda üretimini ve tarımsal verimliliği belirleyen en önemli faktörden birisi iklimdir. Tarımsal üretim; sıcaklık. yağıș ve buharlașma gibi iklim faktörlerinin etkisi altındadır. Bitkinin gelișim dönemi boyunca zamana bağlı olarak sıcaklık ve yağıșın dağılımı ve miktarı tarımsal üretim düzeyini belirlemektedir.

Bitki gelișimi ve verimlilikte bölgeler arasındaki ekolojik farklılıklar büyük rol oynamaktadır (Bauma, 2005). Bir bölge içinde benzer iklim, toprak ve topografik koșullara sahip alanların bir araya getirilmesiyle olușan bölgeler tarımsal ekolojik bölgeler (TEB) olarak tanımlanır (FAO,
1996). Bu alanlarda, iklimsel koșulların çeșitliliğini belirlenmesinde en önemli parametrelerin bir tanesi Tarımsal İklim Bölgeleri (TiB) dir.

Tarımsal İklim Bölgeleri, nemlilik rejimi, bitki büyüme uzunluğu ve mevsimsellik temelinde ekolojik koșulları temsil etmektedir. Bölgeselleștirme yaklașımı ile; verim çeșitliliği ve bitki gelișimini sınırlayıcı faktörleri tanımlaması (Caldiz vd., 2002; Williams vd., 2008), optimum yetiștirme tekniğinin belirlenmesi (Seppelt, 2000), verim eğilimlerinin karșılaștırılması (Gallup ve Sachs, 2000), ișletmelerin üretimi artırmak ve yeni üretim teknolojileri için uygun alanların belirlenmesi (Geerts vd., 2006; Araya vd., 2010) ve iklim değișikliğinin tarım üzerindeki 
etkilerinin analiz edilmesinde (Fischer vd., 2005) kullanılmaktadır. Bölgeselleștirme analizinde, farklı ekolojik parametrelerinin bir araya getirilmesinde Coğrafi Bilgi Sistemi (CBS) teknikleri etkin olarak kullanılmaktadır (FAO, 1996). Ayrıca, bu bölgeler teknolojinin benimsenmesini kolaylaștırmakta ve bu tür teknolojilerin ve araștırmaların verimliliği arttırdığı iklimlerin büyüklüğü, konumu ve özellikleri hakkında fikir vererek yenilikçi yaklașımları teșvik edilmesini sağlamaktadır. Mevcut ekim alanlarının verimliliğini artırmak için gelecekte yeni tarım yöntemlerinin uygulanabileceği benzer bölgeleri belirlemeye yardımcı olmaktadır.

Vejetasyon indisleri bitkilerin zaman bağı olarak gelișimlerindeki farklılıkların ortaya konulmasında kullanılan en etkili yöntemlerden birisidir (Lu vd., 2005). Vejetasyon indisleri uzaktan algılama gözlemleri ve bitki karakteristikleri arasındaki fonksiyonel ilișkiyi bulmak için geliștirilmiștir. Bu indeksler ile su stresi, azot seviyesi gibi bitki gelișimine büyük etkisi olan faktörlerin bitkiler üzerindeki etkileri izlenebilmektedir. Kırmızı ve yakın kızı̈ötesi (NIR) bölgelerindeki spektral yansıması doğrudan bitki biyokütlesi ile ilișkili olduğu gösterilmiștir. Vejetasyon indislerini olușturan kırmızı ve NIR spektral dalga bantlarının matematiksel kombinasyonları, spektrumun her iki bölgesinde bitki yansımasında kullanılmaktadır (Lusch, 1999).

Vejetasyon indis değerleri teorik olarak $(-1)$ ile $(+1)$ arasında değișmektedir. Yeșil bitki örtüsünün fazla olduğu alanlarda indeks değeri +l'e doğru yaklașırken bulutlar, su ve kar düșük (eksi) indeks değerlerine sahiptir. C.ıplak toprak ve zayıf bitki örtüsü durumunda ise sıfıra yakın değeri gösterir (Kogan, 1994). Düșük indeks değerine sahip olan alanlar kuraklık, hastalık ve zararlılar, yetersiz yetiștirme tekniği uygulamaları gibi çeșitli nedenlerle zayıf bitki gelișiminin olduğu bölgeleri ișaret etmektedir. Diğer taraftan yüksek indeks değerleri ise bitki gelișiminin sağlıklı olduğu yerleri göstermektedir.

Bitki gelișim indisleri arasında en yaygın olarak kullanılan vejetasyon indisleri içinde yer alan Normalize Edilmiș Bitki İndeksi (NDVI) ve Zengilleștirilmiș Bitki Örtüsü İndeksi (EVI) dir. Bu vejetasyon indisleri ile bitkilerin biyokütle miktarı, kuraklık, yaprak alan indeksi ve verim ile anlamlı ilișkiler geliștirilmiștir. Uydu görüntülerinden elde edilen bu indisler; bitki gelișiminin izlenmesi (Minamiguchi, 2005), ürün haritalama (Zhang vd., 2011 ) ve verim tahmini (Balaghi vd., 2008; Kouadio vd., 2014) amacıyla yaygın olarak kullanılmaktadır.

Bu çalıșmada, Tarımsal İklim Bölgeleri bazında buğday'ın gelișme dönemi boyunca orta çözünürlüklü MODIS vejetasyon indisleri ile izlenerek verim ve biyokütle arasındaki ilișki düzeyleri araștırılmıștır. Vejetasyon indislerinin zamansal olarak Tỉ'nde etkili olduğu dönemler belirlenerek regresyon modelleri olușturulmuștur.

\section{MATERYAL VE YÖNTEM}

\section{Çalıșma alanı}

Çalıșma alanı, Orta Anadolu Bölgesinde nadas-tahıl tarım üretiminin yoğun olarak yapıldığı Ankara ilininde; Polatlı, Yenimahalle, Bala, Gölbașı, Haymana, Ș.Koçhisar ilçeleri ile Konya ilininde Kulu, Cihanbeyli, Yunak, Kadıhanı Ve Sarayönü ilçelerini kapsamaktadır. Çalıșma alanı, batısında Sakarya nehri, doğusunda Kızılırmak nehri ve güneydoğusunda Tuz gölü ile sınır olușturmaktadır. Alanın yaklașık yüzölçümü $23.000 \mathrm{~km}^{2}$ dir (Șekil 1). Yükselti, $600 \mathrm{~m}$ ile 2000 m arasında değișmektedir. Yarı kurak iklim rejiminin hakim olduğu bölgede, yıllık ortalama sıcaklık $11.7^{\circ} \mathrm{C}$ ve yıllık yağıș toplamı 360 mm dir.

\section{Veri kaynakları}

Modis-Terra (Moderate-resolution Imaging Spectroradiometer) uydu görüntülerinden elde edilen vejetasyon indislerinden, NDVI ve EVI bitki gelișim indisleri kullanılmıștır. Modis uydu görüntüsünün mekansal çözünürlüğü 250 m ve zamansal çözünürlüğü 1-2 gündür. Modis görüntülerinden üretilen vejetasyon indisleri yıl içinde 23 adet görüntü içeren 16 günlük maksimum kompozit verilerdir.

İklim verilerinin elde edilmesinde; Meteroloji Genel Müdürlüğü (MGM) tarafından üretilen. 1975-2015 yılları arasında meteorolojik istasyonlara ait uzun yıllar günlük verileri içeren iklim veri tabanından elde edilen; minimum, maksimum, ortalama sıcaklık, yağıș, nispi nem, rüzgar hızı, güneșlenme süresi parametreleri kullanılmıștır. 


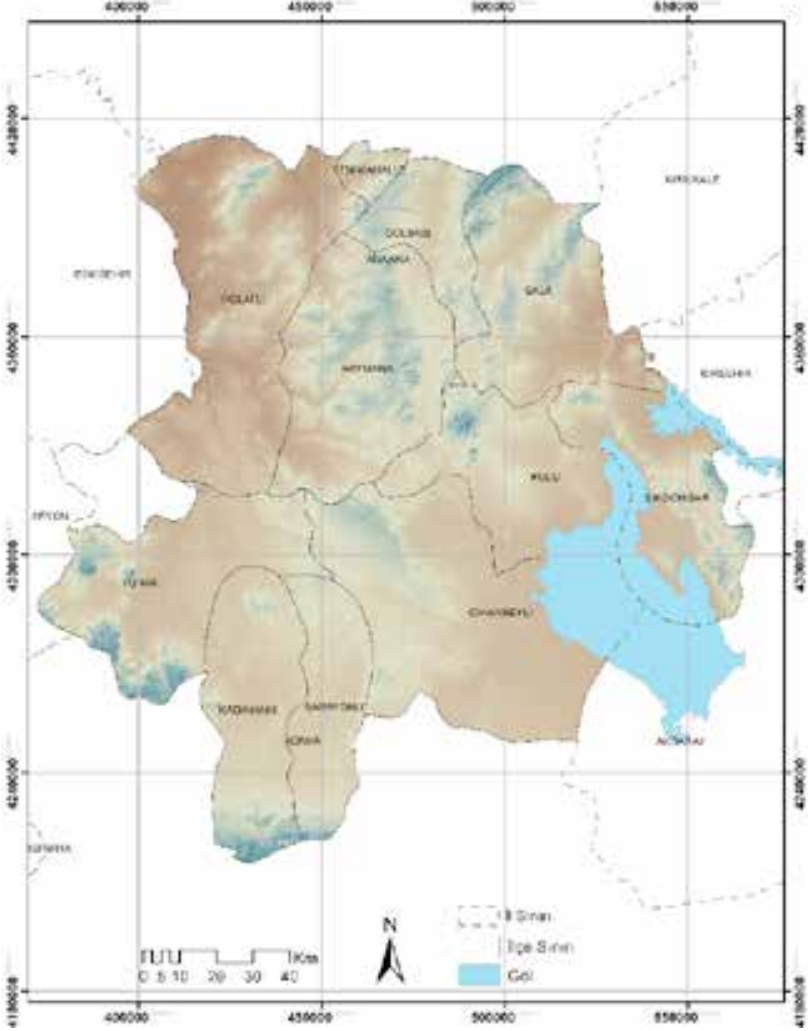

Șekil 1. Çalıșma alanı

Figure 1. Study area

Bitki örneklemesi, 2016 yılı temmuz ayında gerçekleștirilmiștir. Bitki örnekleri, kuru șartlarda ekmeklik buğday üretimi yapılan lokasyonlarında ve parselin üç farklı noktasından $1 \mathrm{~m}^{2}$ lik alanlarda yapılmıștır. Örnekleme lokasyonları, ekolojik bölge içinde bulunan ilçelerin kuru tarım alanlarının yoğunluğu dikkate alınmıș ve seçilen ilçelere bağlı köyler de rastgele örnekleme yöntemi ile çiftçi parselleri belirlenerek yapılmıștır.

\section{İklim parametrelerinin mekânsal dağılımı}

İklim verileri, günlük veri formatından istasyon bazında aylık ortalama verilere dönüștürülmüștür. Meteorolojik istasyonlara ait uzun yıllar aylık ortalamaları içeren noktasal bazlı iklim verileri ile 90 metre çözünürlüklü SRTM (Space Radar Topography Mission) Sayısal Yükseklik Modeli (SYM) verisi ile entegre edilmiștir. Bu amaçla Hutchinson'un (1995) "thin-plate smoothing spline" enterpolasyon tekniği ve ANUSPLIN yazılımı (Hutchinson, 2000) kullanılmıștır. Bu teknikte, hücresel bazda rastgele dağımıș noktasal veriler yükseklik faktörü de dikkate alınarak, alana yayılması ve her hücrenin sayısal olarak değerini tahmin edilmesini sağlayan istatistiksel bir yaklașımdır. iklim yüzey haritaları, CLIMAP
(Pertziger ve De Pauw, 2002) proğramı aracılığıyla raster veri formatında üretilmiștir.

\section{Tarımsal iklim bölgeleri}

Tarımsal iklim bölgeleri (TiB), nemlilik rejimi ve etkili sıcaklık toplamı (EST) olmak üzere iki alt kapsamdan olușmaktadır. Bu kapsamda; nemlilik rejimi, yıllık toplam yağıșın potansiyel evapotranspirasyon miktarına oranını ifade etmektedir. Bu oran aynı zamanda kuraklık indisi (KI) olarak ifade edilmektedir (UNEP, 1993). Referans buharlașma değeri günlük bazda iklim verileri (minimum, maksimum, ortalama sıcaklık, yağıș, nispi nem, rüzgar hızı, güneșlenme süresi) kullanılarak Penman-Monteith (Allen vd., 1998) metoduna göre Eșitlik 1 de verilmiștir. Bu yaklașımda, yağıșla sağlanan su miktarı yanında intiyaç duyulan su talebi de dikkate alınmaktadır. Nemlilik rejimi kendi içinde; yarı kurak-kurakça ve yarı kurak-nemlice olarak sınıflandırılmıștır (Türkeș, 1999).

(Eșitlik 1)

$E T_{0}=\frac{0.408 \Delta(R n-G)+\gamma \frac{900}{T-273} u_{2}\left(e_{s}-e_{a}\right)}{\Delta+\gamma\left(1-0.34 u_{2}\right)}$

Eșitlikte; $\mathrm{ET}_{0}$ : referans buharlașma değeri (mm/gün), T: ortalama sıcaklık $\left({ }^{\circ} \mathrm{C}\right), \Delta$ : buhar basıncı $\left(\mathrm{kPa}{ }^{\circ} \mathrm{C}^{-1}\right) ; \gamma$ : psikrometrik sabit $\left(\mathrm{kPa}{ }^{\circ} \mathrm{C}^{-}\right.$ '), G: toprak ısı akıș yoğunluğu (MJ $\left.\mathrm{m}^{-2} \mathrm{~d}^{-1}\right)$, Rn: net radyasyon $\left(\mathrm{MJ} \mathrm{m}^{-2} \mathrm{~d}^{-1}\right)$, es: Saturasyon buhar basıncı (kPa), ea: Gerçek buhar basıncı $u_{2}: 2 \mathrm{~m}$ yükseklikteki rüzgar hızı (m/s) dır.

Etkili Sıcaklık Toplamı (EST), ürünün gelișiminin fenolojik dönemler bazında değerlendirildiği sıcaklığa dayalı bir göstergedir. Sıcaklık ve ıșık bitkisel üretimde önemli bir rol oynamaktadır. Bitki gelișme dönemi boyunca farklı fenolojik dönemlerin olușumu sıcaklık ile ilișkili olarak toplam derece gün miktarı ile hesaplanmaktadır (Gouri vd., 2005). Buğday'ın gelișiminde belirleyici olan EST gelișme dönemi boyunca Eșitlik 2'ye göre hesaplanmıștır (McMaster ve Wilhelm, 1997).

$$
\begin{array}{ll}
\mathrm{EST}=\sum_{1}^{\mathrm{n}}(\mathrm{Ta}-\mathrm{Tb}) & \mathrm{Ta}>=\mathrm{Tb} \\
\mathrm{EST}=0 . & \mathrm{Ta}<\mathrm{Tb}
\end{array}
$$


Bu eșitlikte; Ta günlük ortalama sıcaklık, $T a=(T m a k+T m i n) / 2$, Tmak günlük maksimum sıcaklık, Tmin: günlük minimum sıcaklık, Tb: bitki büyüme sıcaklığı eșiği (buğday için $5^{\circ} \mathrm{C}$ ) dir. Tarımsal İklim Bölgelerini olușturan parametrelere ait sınıf değerleri Çizelge 1 . de verilmiștir.

Çizelge 1. Tarımsal iklim bölgeleri sınıfları

Table 1. Agro-climatic zones classes

\begin{tabular}{ccc}
\hline Parametre & Sınıf & Açıklama \\
\hline \multirow{3}{*}{ Ki } & $0.20-0.35$ & Yarı kurak-kurakça \\
& $0.35-0.50$ & Yarı kurak-nemlice \\
& $0.50-0.75$ & Yarı nemli \\
& $<1900$ & Soğuk \\
& $1900-2400$ & Serin \\
EST & $2400-2700$ & Sıcak \\
& $2700-3000$ & Çok sıcak \\
& $>3000$ & Așırı sıcak \\
\hline
\end{tabular}

\section{Vejetasyon indisleri}

Normalize Edilmiș Bitki İndeksi (NDVI), vejetasyonun fotosentez kapasitesinin bir göstergesi olarak yakın kızılötesi (NIR) dalga boyu ile kırmızı (RED) bölge dalga boyunun farkının toplamına oranı olarak așağıdaki Eșitlik 3 de ifade edilmiștir (Tucker, 1979).

$$
N D V I=\frac{\rho N I R-\rho r e d}{\rho N I R+\rho r e d}
$$

Zenginleștirilmiș Bitki Örtüsü İndeksi (EVI), atmosfer koșulları ve toprak zemini gibi çevresel faktörlerin olumsuz etkileri azaltılmıștır (Huete vd., 2002). EVI vejetasyon indisi Eșitlik 4 te verilmiștir.

$$
E V I=G \frac{\rho_{\text {NIR }}-\rho_{\text {red }}}{\rho_{\text {NIR }}+C_{1} X \rho_{\text {red }}-\rho_{\text {blue }}+L}
$$

(Eșitlik 4)

$\mathrm{Bu}$ eșitlikte, EVI algoritmasında kullanılan ampirik katsayılar, $L=1 . C 1=6 . C 2=7.5$ ve $G=2.5$ dir. Hem EVI hem de NDVI indeks değerleri -1 ile 1 arasında değișmekte olup yüksek pozitif değerler sağlıklı yeșil bitki örtüsünü göstermektedir. Kayalık ve çıplak alanlar sıfıra yakın değerlere, su ve kar ise negatif değerlere sahiptir.

\section{İstatistiki analiz}

Bu çalıșmada, kıșlık buğday'ın verim ve biyokütlesi ile MODIS uydu görüntüsünden elde edilen bitki gelișim indisleri arasındaki istatistiksel ilișkilerin belirlenmesinde, doğrusal regresyon analizi kullanılmıștır. Regresyon modellerinde tahmin edilmek istenen bağımlı değișken olarak verim ve biyokütle, bağımsı değișkenler ise; gelișme dönemi boyunca uydu görüntülerinden elde edilen NDVI ve EVI bitki gelișim indisleridir. Bu analiz ile TíB bazında gelișme dönemi boyunca etkili bitki gelișim indislerinin belirlenerek verim ve biyokütleye olan ilișki düzeyleri belirlenmiștir.

\section{BULGULAR VE TARTIȘMA}

TiB, temel iklim parametrelerinin kullanılması sonucu üretilen nemlilik ve sıcaklık rejimi indislerinden olușturulmuștur. Nemlilik rejimi aynı zamanda kuraklık indisi olarak ifade edilmektedir. Yarı kurak iklim șartlarının hakim olduğu bölgede, bölgeler arasındaki farklılığının ortaya çıkması için yarı kurak kurakça ve yarı kurak nemlice olmak üzere iki alt kapsama ayrılmıștır. Diğer bir ana parameter olan sıcaklık rejiminin belirlenmesinde, Etkili Sıcaklık Toplamı (EST) parametresi kullanıımıștır. EST ürünün bitki gelișim dönemi uzunluğunun belirlenmesinde kullanılan ana parametrelerden birisidir. Bu kapsamda, buğday'ın bölgesel bazda gelișimindeki farklılıkları belirlenmiștir.

Çalıșma alanı 5 farklı tarımsal iklim bölgesini içermektedir (Șekil 2). En yaygın olan bölge TiB5 (\%33.8) olurken bu bölgeyi sırasıyla; TiB4 (\%27.6), TiB2 (\%23.9), TiB3 (\%7.3) ve TiB1 (\%7.2) bölgeler

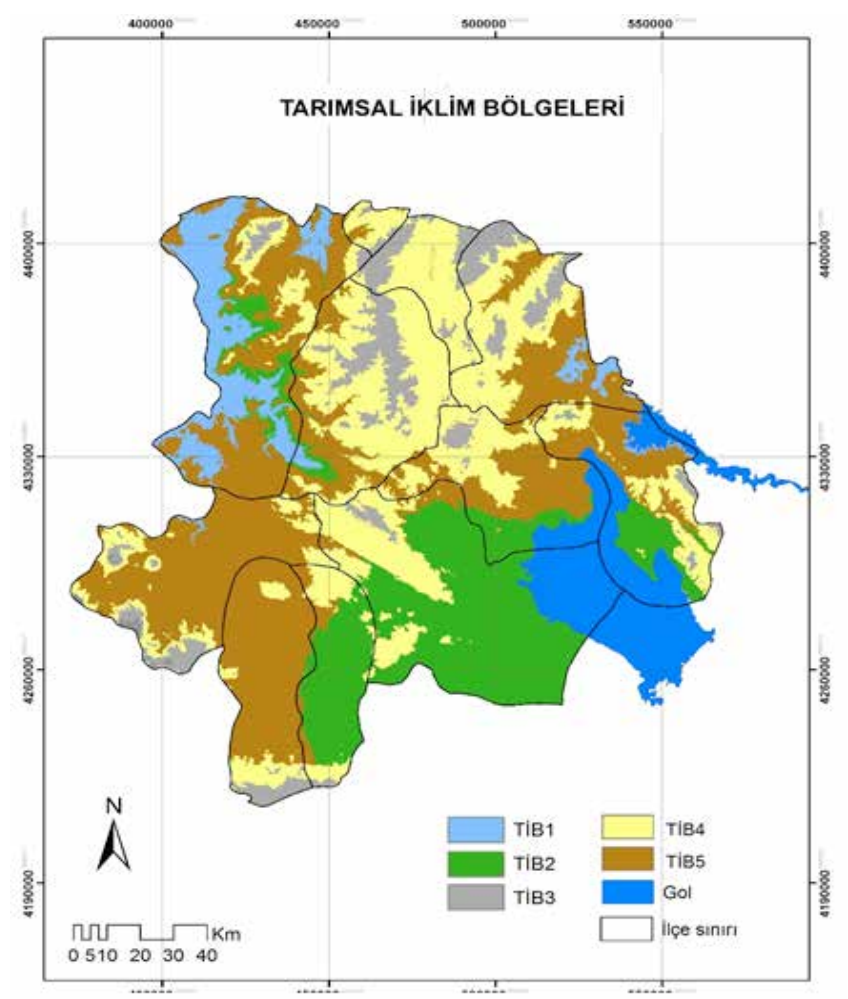

Sekil 2. Calıșma alanı

Figure 2. Study area 
Çizelge 2. TiB bazında biyokütle ve verim değerleri

Table 2. Biomass and yield values on TIB basis

\begin{tabular}{ccccccccc}
\hline \multicolumn{9}{c}{ Biyokütle $(\mathrm{kg} / \mathrm{da})$} \\
\hline \multirow{2}{*}{ TiB } & Ort & Min & Mak & Std_hata & Ort & Min & Mak & Std_hata \\
\hline 1 & 886.2 & 731.1 & 1009.6 & 27.2 & 369.2 & 285.2 & 430.0 & 14.3 \\
2 & 667.8 & 281.5 & 1232.0 & 57.5 & 255.8 & 105.0 & 470.0 & 23.2 \\
3 & 1040.6 & 827.4 & 1324.4 & 63.7 & 386.5 & 277.0 & 509.3 & 26.8 \\
4 & 964.7 & 600.0 & 1389.0 & 36.2 & 355.2 & 199.3 & 506.7 & 13.4 \\
5 & 846.1 & 294.1 & 1411.9 & 48.9 & 327.5 & 121.5 & 512.2 & 17.6 \\
\hline
\end{tabular}

takip etmektedir. TiB55 bölgesinde rakım $850 \mathrm{~m}$ ile $1000 \mathrm{~m}$ arasında değișim gösterirken iki hat boyunca yayllım göstermektedir. (1) Polatlı, Yunak ve Kadıhanı ilçeleri boyunca, (2.) Kulu, Bala,ve Ș.koçhisar ilçelerini kapsamaktadır.

TiB1 bölgesi, en yüksek sıcaklık toplamına (EST > 3000 derece gün) sahip bölge olup Polatı ilçesinde sakarya nehri boyunca, 800 m rakıma kadar olan alanlarda dağlım göstermektedir. TiB3 bölgesi ise serin iklim bölgesi sınıfında olup Haymana ilçesinde 1200 müzerinde rakımlı alanları kapsayan ve çalıșma alanı içerisinde EST değeri en düșük 11900-2400 derece gün) bölgeleri kapsamaktadır. Tuz gölü ve çevresinde yaygın olarak dağılım göstermekte olan TiB2 bölgesi ise yarı kurak-kurakça nemlilik rejiminde ve EST değeri 2700-3000 derece gün olan bölgeleri karakterize etmektedir. TiB3 bölgesi ise çalıșma alanının orta kesimi boyunca ve 10001200 m rakıma sahip olan Haymana, Gölbașı ve Bala ilçelerinde yaygın bir dağııım göstermektedir.

Arazi çalıșmalarında, 108 lokasyondan bitki mataryeli toplanmıștır. TiB bazında toplanan bitki örneklerine ait verim ve biyokütle değerleri arasındaki ilișkiler değerlendirilmiștir. En yüksek verim değeri TiB3 de $386.5 \mathrm{~kg} / \mathrm{da}$ olurken. en düșük verim ortalaması Tï2 de 255.8 kg/da dır. Biyokütle açısından en yüksek verim TiB3 de 1040.6 da/kg iken en düșük değer TiB2 de 667.8 kg/da olarak gerçekleșmiștir (Çizelge 2).

Çizelge 3. Vejetasyon indis dönemleri

Table 3. Vegetation indices periods

\begin{tabular}{|c|c|c|c|}
\hline Dönem & Tarih & Dönem & Tarih \\
\hline 1 & 01 Kasım-16 Kasım & 9 & 06 Mart-21 Mart \\
\hline 2 & 17 Kasım-02 Aralık & 10 & 22 Mart-06 Nisan \\
\hline 3 & 03 Aralık- 18 Aralık & 11 & 07 Nisan-22 Nisan \\
\hline 4 & 19 Aralık- 03 Ocak & 12 & 23 Nisan-08 Mayıs \\
\hline 5 & 01 Ocak-17 Ocak & 13 & 09 Mayıs-24 Mayıs \\
\hline 6 & 18 Ocak-17 Șubat & 14 & 25 Mayıs-09 Haziran \\
\hline 7 & 18 Șubat-05 Mart & 15 & 10 Haziran-25 Haziran \\
\hline 8 & 06 Mart-21 Mart & & \\
\hline
\end{tabular}

Bitki gelișimi boyunca 15 adet dönem için 16 günlük periyodlarda elde edilen vejetasyon indisleri ile verim ve biyokütle arasındaki ilișkiler değerlendirilmiștir (Çizelge 3).

Bitki gelișim dönemi içinde hem NDVI hem de EVI indislerinin en yüksek değere ulaștığı, bașaklanma/çiçeklenme dönemi için 12. ve 13. dönemler öne çıkmıștır. En zayıf gelișim hem NDVI hemde EVI indisleri için TIB2 de gözlenmiștir. En iyi gelișim ise TiB3 de rakımı yüksek olan alanlarda görülmüștür (Șekil 3).

Çalıșma alanında, 2015-2016 sezonluk yağıș dağılımı fenolojik dönem bazında incelenmiștir (Șekil 4). Ekim ișlemi gerçekleștikten sonra ekim ayında düșen yağıșlar ile çıkıșların gerçekleștiği daha sonra kasım ve aralık ayında yeterli yağıșların

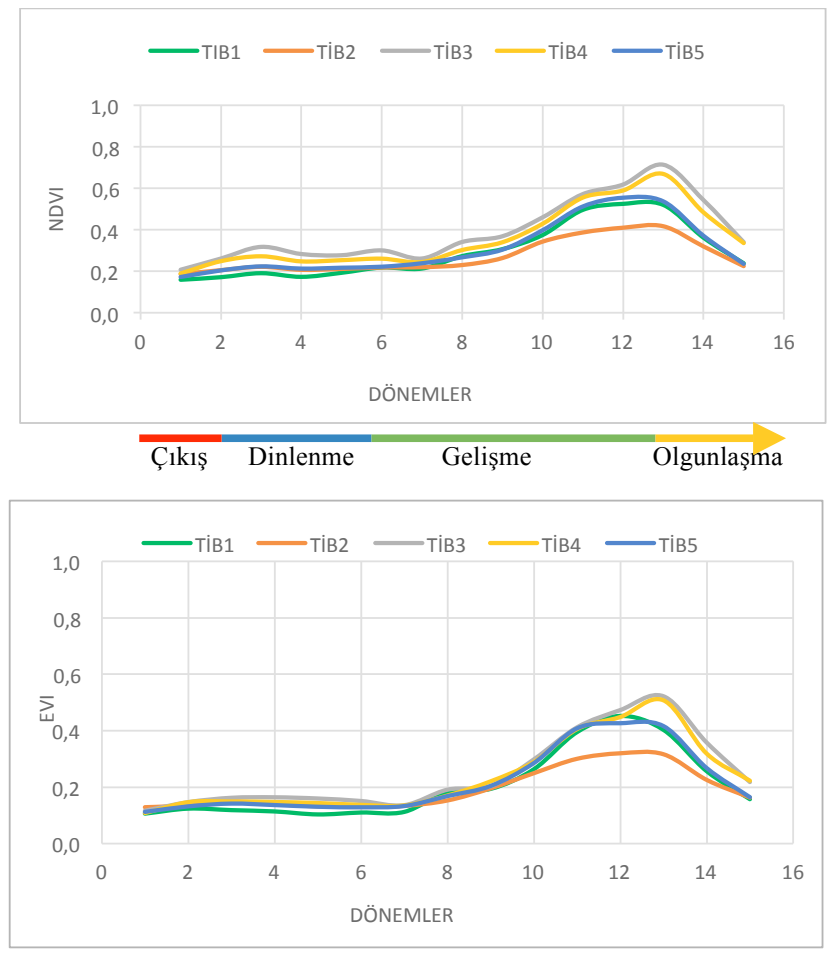

Șekil 3. TíB bazında vejetasyon indislerinin zamansal değișimi Figure 3. Temporal variation of vegetation indices on TIB basis 
alınmadığı görülmüștür. Vejatasyon gelișiminin en hızlı olduğu dönemler olan nisan ayında düșük bir yagișın gerçekleșmesi ve mayıs ayının sonlarına doğru yağıșların gerçekleșmesi sebebiyle özellikle düșük rakımlı alanlar olumsuz etkilenmiș ve bitkinin strese girdiği parseller gözlenmiștir. Yüksek rakımlı alanların ise bașaklanma/çiçeklenme fenolojik dönemi itibariyle yağıșlardan daha çok faydalandığı gözlenmiștir. Çalıșma alanında en yüksek biyokütle ve verim değerleri TiB3 ve TiB4'ünde içinde olduğu bu bölgelerde elde edilmiștir.

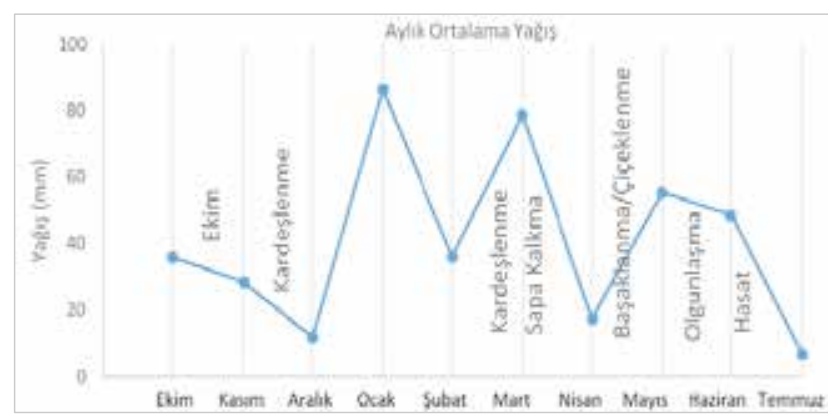

Șekil 4. 2015-2016 sezonu aylık yağıș değișimi ve buğday fenolojik dönemleri (Ankara meteorolojik istasyonu)

Figure 4. 2015-2016 season rainfall pattern and wheat phenological stage (Ankara meteorological station)

Çalıșma alanının geneli için vejetasyon indisleri ile verim ve biyokütle arasındaki ilișkiler incelenmiștir (Çizelge 4). Biyokütle için bütün dönemler NDVI için önemli bulunurken. EVI indisi için 2 ve 15. dönemler arasında önemli bulunmuștır. Vejetasyon indisleri ile biyokütle arasında en yüksek ilișki; NDVI için 12. dönem (\%75) ve 13. dönem (\%72), EVI için 12. dönem (\%71) ve 13. dönemlerde (\%72) gerçekleșmiștir. Vejetasyon indisleri ile verim arasındaki ilișkiler incelendiğinde NDVI ve EVI için 2 ile 15. dönemler arasında önemli düzeyde ilișkiler bulunmuștur. Vejetasyon indisleri ile verim arasında en yüksek korelasyon oranı 12. dönemde, NDVI (\%72) ve EVI (\%70) olarak gözlenmistir. Vejetasyon indislerinin 11 ve 13. dönemler arasında verim ve biyokütle ile yüksek korelasyonların oluștuğu gözlenmiștir. Bu dönemler buğday'ın vejetatif gelișme dönemi içinde sapa kalkma ile çiçeklenme dönemi arasındaki zamanı kapsamaktadır.

Tarımsal İklim Bölgeleri bazında verim ve biyokütle ile vejetasyon indisleri değerlendirildiğinde, buğday'ın çıkıș döneminden bașlayarak olgunlașmaya kadar fenolojik dönem (FD) bazında farklı vejetasyon indislerinin öne çıktığı
Çizelge 4. Biyokütle ve verim ile vejetasyon indisleri arasındaki korelasyon değerleri

Table 4. Correlation rates between biomass and yield and vegetation indices

\begin{tabular}{ccccc}
\hline \multicolumn{4}{c}{ NDVI } & \multicolumn{2}{c}{ EVI } \\
\hline Dönem & Biyokütle & Verim & Biyokütle & Verim \\
\hline 1 & $0.199 *$ & 0.138 & 0.090 & 0.048 \\
2 & $0.411 * *$ & $0.346 * *$ & $0.336 * *$ & $0.297 * *$ \\
3 & $0.498 * *$ & $0.417 * *$ & $0.323 * *$ & $0.257 * *$ \\
4 & $0.450 * *$ & $0.398 * *$ & $0.344 * *$ & $0.307 * *$ \\
5 & $0.427 * *$ & $0.381 * *$ & $0.351 * *$ & $0.302 * *$ \\
6 & $0.495 * *$ & $0.467 * *$ & $0.398 * *$ & $0.378 * *$ \\
7 & $0.517 * *$ & $0.494 * *$ & $0.413 * *$ & $0.387 * *$ \\
8 & $0.534 * *$ & $0.509 * *$ & $0.416 * *$ & $0.399 * *$ \\
9 & $0.550 * *$ & $0.525 * *$ & $0.407 * *$ & $0.378 * *$ \\
10 & $0.542 * *$ & $0.516 * *$ & $0.479 * *$ & $0.468 * *$ \\
11 & $0.688 * *$ & $0.660 * *$ & $0.663 * *$ & $0.609 * *$ \\
12 & $0.746 * *$ & $0.726 * *$ & $0.705 * *$ & $0.695 * *$ \\
13 & $0.723 * *$ & $0.678 * *$ & $0.719 * *$ & $0.658 * *$ \\
14 & $0.611 * *$ & $0.529 * *$ & $0.555^{* *}$ & $0.465 * *$ \\
15 & $0.448 * *$ & $0.336 * *$ & $0.372 * *$ & $0.267 * *$ \\
\hline
\end{tabular}

* ilișki 0.05 seviyede önemlidir.

** ilișki 0.01 seviyede önemlidir

görülmüștür. Özellikle, buğday'ın gelișme dönemi içinde sapa kalkma dönemi (SK) ve bașaklanma/ çiçeklenme dönemi (BÇ) önem tașımaktadır. İstatistik analizler de olușturulan regresyon modelleri için SK ve BÇ dönemleri bazında bağımsız değișkenlerin önemlilik düzeylerine göre etkili vejetasyon indisleri belirlenmiștir.

Biyokütle ile NDVI arasında en yüksek ilișki TỉB1 de SK de \%80 ve BÇ dönemlerin de \%84 düzeyinde görülmüștür. SK dönemin de, TíB3 (\%65) ve TiB5 (\%56), BC dönemin de ise TiB3 (\%60) ve TíB5 (\%58) izlemiștir. Biyokütle ile EVI arasında en yüksek ilișki TỉB5 de SK dönemin de \%62 ve BÇ dönemin de TiBl de \%68 oranında görülmüștür. SK döneminde, TïB3 (\%65), BÇ döneminde ise TiB3 (\%60) ve TiB5 (\%62) düzeyinde gözlenmiștir. Butun lokasyon verilerinin ele alındığında ise biyokütle ile NDVI arasında SK döneminde \%47 ve BÇ dönemin de \%56, biyokütle ile EVI arasında SK döneminde $\% 66$ ve BÇ döneminde \%62 oranlarında gerçekleșmiștir (Çizelge 5).

Verim ile NDVI arasında en yüksek ilișki TiB 1 de SK de \%68 ve BÇ dönemlerin de \%72 düzeyinde görülmüștür. SK dönemin de, TiB3 (\%54) ve TiB2 (\%51), BC döneminde ise TiB5 (\%56) ve TiB3 (\%54) sırasıyla izlemiștir. Verim ile EVI arasında 
Çizelge 5. TíB bazında biyokütle ve vejetasyon indisleri arasında istatistiki model değerleri

Table 5. Statistical model values between biomass and vegetation indices on TIB basis

\begin{tabular}{cccccccc}
\hline & \multicolumn{7}{c}{ Biyokütle-NDVI } \\
\hline & FD & Regresyon modeli & $\mathrm{P}$ & $\mathrm{R}^{2}$ & Regresyon modeli & $\mathrm{P}$ & $\mathrm{R}^{2}$ \\
\hline \multirow{2}{*}{ TiB 1 } & SK & $y=590.2+596.7 \times 11$ & 0.000 & 0.80 & $y=732.4+389.2 \times 11$ & 0.024 & 0.49 \\
& BC & $y=464.1+803.4 \times 13$ & 0.000 & 0.84 & $y=609.3+687.3 \times 13$ & 0.003 & 0.68 \\
\hline \multirow{2}{*}{ TiB 2 } & SK & $y=135.8+1322 \times 11$ & 0.000 & 0.53 & $y=260.5+1355.2 \times 11$ & 0.006 & 0.33 \\
& BC & $y=267.5+1035.4 \times 12$ & 0.000 & 0.51 & $y=343.8+1069.3 \times 12$ & 0.001 & 0.43 \\
\hline \multirow{2}{*}{ TiB 3 } & SK & $y=81.9+1550.9 \times 12$ & 0.016 & 0.65 & $y=440.5+1268.3 \times 12$ & 0.015 & 0.65 \\
& BC & $y=343.6+1283.3 \times 14$ & 0.027 & 0.60 & $y=353.1+1921.3 \times 14$ & 0.027 & 0.60 \\
\hline \multirow{2}{*}{ TiB 4 } & SK & $y=463.0+850.9 \times 12$ & 0.002 & 0.27 & $y=582.1+852.8 \times 12$ & 0.007 & 0.22 \\
& BC & $y=465.5+745.9 \times 13$ & 0.022 & 0.16 & $y=479.2+956.2 \times 13$ & 0.004 & 0.24 \\
\hline \multirow{2}{*}{ TiB 5 } & SK & $y=69.1+1271.9 \times 11$ & 0.000 & 0.56 & $y=184.3+1620.0 \times 11$ & 0.000 & 0.66 \\
& BC & $y=178.7+1203.1 \times 13$ & 0.000 & 0.58 & $y=247.6+1437.8 \times 13$ & 0.000 & 0.62 \\
\hline \multirow{2}{*}{ Genel } & SK & $y=219.6+1210.5 \times 12$ & 0.000 & 0.47 & $y=351.0+1332.6 \times 11$ & 0.000 & 0.44 \\
& BC & $y=225.8+1210.5 \times 12$ & 0.000 & 0.56 & $y=322.4+1259.613$ & 0.000 & 0.52 \\
\hline
\end{tabular}

en yüksek ilișki TiB33 de SK dönemin de \%51 ve BC döneminde TiB1 de \%54 oranındadır. SK döneminde, TiB5 (\%49), BC döneminde ise TiB3 (\%51) ve TiB5 (\%49) düzeyinde gözlenmiștir. Butun Iokasyon verilerinin ele alındığında ise verim ile NDVI arasında SK döneminde \%44 ve $\mathrm{BC}$ dönemin de \%53, verim ile EVI arasında SK döneminde \%37 ve BC döneminde \%48 oranlarında gerçekleșmiștir (Çizelge 6). TiB bazında model sonuçlarına ekolojik bölgelerden alınan örnekleme sayıları da etki etmektedir. Ekolojik bölgeyi temsil edecek sayıda örneklemenin yapılması model performanslarının artmasını sağlayacaktır. Çalıșma alanının genelinde NDVI ve EVI indisleri kullanılarak olușturulan modellerde büyük bir farklılık gözlenmemiștir.
TiB'ne göre farklı vejetasyon indislerinin etkin olması, model sonuçlarında farklılıklar olușmasını sağlamıștır. TỉB bazında önemlilik düzeyleri $(p<0.05)$ dikkate alınarak belirlenen etkili vejetasyon indisleri için olușturulan hem NDVI hemde EVI tabanlı modellerde vejetatif gelișim döneminde genellikle 11. dönemin öne çıkmaktadır. Yüksek rakımlı bölgelerde ise 12 . dönemin etkili olduğu görülmüștür. Bașaklanma/ Çiçeklenme döneminde ise çalıșma alanının genelinde ise 13. dönemin yaygın olarak öne çıkmaktadır. Bu alanların dıșında, Tuz gölü ve civarında 12. dönemin ve Haymana gibi yüksek rakımlı bölgelerde ise 14. dönemin öne çıktığı gözlenmiștir.

Çizelge 6. TiB bazında verim ve vejetasyon indisleri arasında istatistiki model değerleri

Table 6. Statistical model values between yield and vegetation indices on TIB basis

\begin{tabular}{cccccccc}
\hline \multicolumn{7}{c}{ Verim-NDVI } & \multicolumn{7}{c}{ Verim-EVI } \\
\hline & FD & Regresyon modeli & $\mathrm{P}$ & $\mathrm{R}^{2}$ & Regresyon modeli & $\mathrm{P}$ & $\mathrm{R}^{2}$ \\
\hline \multirow{2}{*}{ TiB 1 } & SK & $y=225.3+290.0 \times 11$ & 0.003 & 0.68 & $y=295.2+187.5 \times 11$ & 0.045 & 0.41 \\
& BC & $y=163.1+392.3 \times 13$ & 0.002 & 0.72 & $y=235.3+296.1 \times 12$ & 0.015 & 0.54 \\
\hline \multirow{2}{*}{ TiB 2 } & SK & $y=45.6+522.2 \times 11$ & 0.000 & 0.51 & $y=90.2+550.9 \times 11$ & 0.006 & 0.34 \\
& BC & $y=98.3+407.4 \times 12$ & 0.000 & 0.49 & $y=125.4+430.3 \times 12$ & 0.001 & 0.43 \\
\hline \multirow{2}{*}{ TiB 3 } & SK & $y=47.3+592.9 \times 11$ & 0.037 & 0.54 & $y=164.1+469.9 \times 12$ & 0.046 & 0.51 \\
& BC & $y=106.1+516.2 \times 14$ & 0.038 & 0.54 & $y=117.3+752.3 \times 14$ & 0.047 & 0.51 \\
\hline \multirow{2}{*}{ TiB 4 } & SK & $y=167.5+318.3 \times 12$ & 0.002 & 0.28 & $y=196.2+354.4 \times 12$ & 0.002 & 0.27 \\
& BC & $y=114.1+360.2 \times 13$ & 0.002 & 0.28 & $y=148.0+408.2 \times 13$ & 0.000 & 0.32 \\
\hline \multirow{2}{*}{ TiB 5 } & SK & $y=69.9+502.7 \times 11$ & 0.000 & 0.48 & $y=122.9+500.7 \times 11$ & 0.000 & 0.49 \\
& BC & $y=61.5+495.2 \times 12$ & 0.000 & 0.56 & $y=137.4+456.8 \times 13$ & 0.000 & 0.49 \\
\hline \multirow{2}{*}{ Genel } & SK & $y=99.0+455.9 \times 11$ & 0.000 & 0.44 & $y=154.1+456.2 \times 11$ & 0.000 & 0.37 \\
& BC & $y=98.0+439.6 \times 12$ & 0.000 & 0.53 & $y=139.5+1459.4 \times 12$ & 0.000 & 0.48 \\
\hline
\end{tabular}




\section{SONUÇLAR}

Bu çalıșmada, 250 m mekânsal çözünürlüklü ve 16 günlük kompozit MODIS uydu görüntüsünden elde edilen NDVI ve EVI vejetasyon indisleri kullanıımıștır. Çalıșma alanı yarı kurak iklim rejimine sahip olmasına rağmen bölge içindeki ekolojik farklılıklar nedeniyle farklı vejetasyon indisleri öne çıktığı görülmüștür. Arazi çalıșmalarında, düșük rakımlı alanlar ile yüksek rakımlı alanlar arasındaki 15-20 günlük fenolojik farklı̈ı̆ın olușturulan modellerde öne çıkan indisler ile uyumlu olduğu gözlenmiștir. Aynı zamanda bu değerlendirmelerin yıllar bazında yapılması da önem tașımaktadır. Yıllar bazında yağıș dağılımlarındaki düzensizlik ve dağınıklık fenolojik dönemlerde kaymalara yol açması muhtemeldir. Bu durum ekolojik bölge bazında bitki gelișimine ve dolayısıyla verime etki etmektedir. Çiftçi tarlaları için MODIS uydu görüntüsünün mekânsal ve zamansal çözünürlüğü fenolojik farklılıkların izlenmesinde olumlu sonuç verirken verim açısından \%55 civarında bir ilișki oranı belirlenmiștir. Daha yüksek bir ilișki düzeyine ulașılmasında mekânsal çözünürlüğün artmasını sağlayacak yüksek çözünürlüklü uydu görüntülerinin kullanııması önem tașımaktadır.

Verim tahmin modellerinin olușturulmasında bağımsız değișkenlerin bağlı değișken üzerindeki etkilerinin ortaya konulması modelin doğruya yakın tahminde bulunabilmesi açısından önemlidir. Bitki gelișimine ekolojik faktörler, çeșit özellikleri, yetiștirme tekniği gibi birçok faktör önem tașımaktadır. Vejetasyon indisleri, bitki gelișimine etki eden bu faktörlerin olumlu veya olumsuz etkilerinin ortaya konulmasında ve gelișimin izlenmesinde etkin bir șekilde kullanılmaktadır. TiB bazında yapılan tahmin modelleri içinde alanın bütününde yapılan tahminlere göre daha iyi sonuçlar alındığı görülmüștür. Büyük alanlarda bütünsel yaklașımlara göre bölgeselleștirme temelli modellerin olușturulması ile tahminlerin daha sağlıkı yapılabilmesi sağlanabilecektir.

\section{TEȘEKKÜR}

Buçalıșma, TÜBiTAK-300 1 programıkapsamında, 1050850 nolu proje ile desteklenmiștir.

\section{KAYNAKLAR}

Allen RG, Pereira LS, Raes D, Smith M (1998). Crop evapotranspiration: Guideline for computing crop water requirements.FAO No56
Araya A, Keesstra SD, Stroosnijder L (2010). "A new agroclimatic classification for crop suitability zoning in northern semi-arid Ethiopia". Agric. Forest Meteorol. 150. 1057-1064.

Balaghi R, Tychon B, Eerens $H$, Jlibene M (2008). "Empirical regression models using NDVI, rainfall and temperature data for the early prediction of wheat grain yields in Morocco", International Journal of Applied Earth Observation and Geoinformation, 10, pp. 438-452.

Bouma E (2005). Development of comparable agroclimatic zones for the international exchange of data on the efficacy and crop safety of plant protection products. OEPP/ EPPO. Bulletin OEPP/EPPO Bulletin. 35. 233- 238 Plant Protection Service. Geertjesweg 15. PO Box 9102 . NL-6700 HC Wageningen (Netherlands).

Caldiz DO, Haverkort AJ, Struik PC (2002). “Analysis of a complex crop production system in interdependent agroecological zones: a methodological approach for potatoes in Argentina". Agric. Syst. 73. 297-311.

FAO (1996). Agro-Ecologıcal Zoning Guidelines. Soil Bulletin. vol. 73. FAO. Rome.

Fischer G, Shah M, Tubiello FN, Van Velhuizen H (2005). "Socio-economic and climate change impacts on agriculture: an integrated assessment. 1990-2080". Phil. Trans. R. Soc. Lond. B 360. 2067-2083.

Gallup JL, Sachs JD (2000). “Agriculture. climate. and technology: why are the tropics falling behind?". Am. J. Agric. Econ. 82. 731-737.

Geerts S, Raes D, Garcia M, Del Castillo C, Buytaert W (2006). "Agro-climatic suitability mapping for crop production in the Bolivian Altiplano: a case study for quinoa". Agric. Forest Meteorol. 139. 399-412.

Gouri V, Reddy DR, Rao SBSN, Rao AY (2005). Thermal requirement of rabi groundnut in southern Telengana zone of Andhra Pradesh. J. Agrometeorol..7: 90-94.

Hutchinson MF (2000). ANUSPLIN version 4.1. User guide. center for resource and environmental studies, Australian National University, Canberra.

Hutchinson MF (1995). Interpolating mean rainfall using thin plate smoothing splines. Int. J. Geogr. Info. Systems, 9: 385-403.

Huete A, Didan K, Miura T, Rodriguez E P, Gao X, Ferreira $L G$ (2002). Overview of the radiometricand biophysical performance of the MODIS vegetation indices. Remote Sens. Environ. 83, 195-213.

Lu D, Mausel P, Batistella M, Moran E (2005). Landcover binary change detection methods for use in the moist tropical region of the Amazon. International Journal of Remote Sensing. Vol. 26. No. 1. pp. 101-114.

Lusch D P (1999). Introduction to Environmental Remote Sensing: Michigan: Center for Remote Sensing and GIS.

Kogan F (1994). NOAA plays leadership role in developing satellite technology for drought watch. Earth Observation Magazine. EMO Inc.. Littleton. CO. USA. pp. 18-20. 
Kouadio L, Newlands N K, Davidson A, Zhang $Y$, Chipanshi A (2014). "Assessing the Performance of MODIS NDVI and EVI for Seasonal Crop Yield Forecasting at the Ecodistrict Scale." Remote Sensing 6: 10193-10214. doi:10.3390/rs61010193.

Mcmaster G S, Wilhelm W (1997). Growing degreedays:one equation. two interpretations. Agric. For. Meteorol. 87(4):291-300. doi:10.1016/S0168-1923(97)00027-0.

Minamiguchi N (2005). The Application of geospatial and disaster information for food insecurity and agricultural drought monitoring and assessment by the FAO GIEWS and Asia FIVIMS // Proceedings of the Workshop on Reducing Food Insecurity Associated with Natural Disasters in Asia and the Pacific. Bangkok. P. 20-21.

Pertziger F, De Pauw E (2002). CLIMAP. An Excel-based software for climate surface mapping. ICARDA, Aleppo, Syria.

Rouse J W, Haas R H, Schell J A, Deering DW (1973). Monitoring vegetation systems in the Great Plains with ERTS. Proceedings of the Third ERTS Symposium. NASA SP-351. Washington. DC. NASA. p. 309-317.

Seppelt R (2000). Regionalised optimum control problems for agroecosystem management. Ecol. Model. 131. 121-132.
Tucker C (1979). Red and photographic infrared linear combination for monitoring vegetation. Remote sensing of Environment. 8. 127- 150.

Turkes M (1999). Vulnerability of Turkey to desertification with respect to precipitation and aridity conditions, Tr. J. of Engineering and Environmental Science, 23 (1999), 363380. TUBITAK.

UN-DESA (2013). World Population Prospects: The 2012 Revision. United Nations Department of Economic and Social Affairs. Population Division. New York. http://esa.un.org/ unpd/wpp/index.htm.

UNEP (1993). World atlas of desertification. The United Nations Environment Programme (UNEP), London.

Zhang S, Lei Y, Wang L, Li H, Zhao H (2011). Crop Classification Using MODIS NDVI Data Denoised by Wavelet: A Case Study in Hebei Plain. China. Chin. Geogra. Sci. 2011 21(3) 322-333 doi: 10.1007/s1 1769-011-0472-2.

Williams CL, Liebman M, Edwards JW, James DE, Singer JW, Arritt R, Herzmann D (2008). Patterns of regional yield stability in association with regional environmental characteristics. Crop Sci. 48. 1545-1559. 